\title{
Influence of Microfinance Credits on the Socio-economic Status of Women in Edo State, Nigeria
}

\author{
Taiwo, Patricia A. \\ Department of Sociology, Faculty of the Social Sciences, University of Ibadan
}

\begin{abstract}
This paper examines the influence of microfinance credits on womens' socio-economic status in Edo state in both microfinance that offer health-related services and those that do not. The Objectives include examining the process through which women access microfinance loans and the role of microfinance on women's socioeconomic status. Social action and functionalist formed the theoretical frameworks. Questionnaire was administered to 750 purposively selected females' microfinance clients with 400 drawn from Microfinance Institutions that offer health related programs and 350 drawn from microfinance institutions that do not offer health related services. Qualitative data were elicited from 14 In-depth Interviews (IDIs) with union representatives, 20 Key Informant Interviews (KIIs) with microfinance officials and 8 Focus Group Discussions (FGDs) with clients. Although, more women from microfinance without health related services reported experiencing more difficulty in accessing loans (24.7\%) than those win microfinance with health related services (5.5\%), study findings still revealed that access to microfinance positively influenced women's socio-economic status (income $(\mathrm{r}=.023)$, occupation $(\mathrm{r}=.043)$ and education $(\mathrm{r}=.051)$. Qualitative data also buttressed the role of micro credit in that it enabled clients contribute to meeting household needs, expanded their businesses and generally reduced poverty. While the study concludes that microfinance empowers women socio-economically, it still argues that the very poor women in the society for which microfinance is targeted are still unreached and therefore poverty alleviation is not maximally achieved through this intervention. Thus, more funds and support from government, philanthropists and international agencies are required for effective poverty alleviation.

Keywords: Health-related, Microfinance, Poverty, Women empowerment, Socio-economic, Poverty alleviation DOI: $10.7176 /$ JPID/48-04
\end{abstract}

\section{Introduction/Statement of the problem}

Poverty and its numerous consequences of lack, inequality, feeling of deprivation, powerlessness, dependency and poor health especially among women in Nigeria have attracted the attention of the global community. Women constitute about half of the Nigerian population (Otite and Ogionwo 2006,) while over 70 percent of them contribute to the agricultural sector (Aina 1998, Otite and Ogionwo 2006). However, a huge proportion of them lack economic empowerment (Olutayo 2005) and this has implication for their socio-economic status and contribution to national development. Again, women play important role in the aspect of reproduction and continuity in the Nigerian society and are faced with the challenges of maternal and infant mortality (Nwokocha, 2005). In addition, despite the fact that Nigeria is blessed with both human and material resources, poverty is still endemic among her people especially women (Sofo and Toni, 2008). This is further compounded by the experience of poverty-induced sicknesses such as malaria and HIV/AIDS which according to Dunford (2002) have formed part of the priority concerns in the millennium development goals (MDGs).

Microfinance was introduced for over three decades ago to reach out to poverty-stricken families especially women with the aim of reducing poverty and improving the standard of living of clients and in turn their family members (Daley-Harris, 2002). Through this intervention, millions of women have been empowered socioeconomically, with micro credit, to start new businesses, expand old ones and create wealth. This is expected to help women become financially independent and experience improvement in their self-image, confidence and esteem. (MkNelly and Dunford 1998). These notwithstanding, women still form the bulk of the poor and less empowered in the Nigerian society (Olutayo, 2005). The challenges of marginalization and inequality experienced by women in a country faced with high level of political and economic insecurity aggravates their difficulty in repaying loans (Irobi, 2007) and contributing adequately to national development (Sofo and Toni, 2008). This may not be far from the fact that many women in Nigeria, spend their income on their household even in matters that concerns health and contribution to children's up-keep and support husbands (Irobi, 2007). Taiwo and Owumi (2012) had emphasized the need to integrate health related programmes in all microfinance institutions to reduce the effects it has on women's productivity and ability to repay loans collected and in turn ensure sustainable development. The improvement of the socio-economic status of women is dependent on their access to credit which is a function of the group influence and previous loan repayment (Taiwo, Owumi and Oyekanmi, 2017). This further determines subsequent access to credits that may enable women expand their businesses, social capital and in turn socio-economic status. This paper therefore examine the influence of microfinance on the empowerment of women and specifically does this by comparing the groups from microfinance banks with health related services and those without health related services and the implication it 
has for poverty alleviation in Nigeria. It specifically seeks to discuss the process through which women access microfinance loans, examine the influence of microfinance on women's socio-economic status and document the set and achieved goals of women as microfinance clients.

\section{Structural Functionalism Theory}

The functionalists adopt the idea of interconnectedness, interdependence and inter-relatedness of its parts to explain societal survival. Thus, the existence and continuity of society is analysed from the functions institutions and structures in it. The concepts of manifest and latent function are also components of this theoretical model. Manifest function is simply viewed as those that are intended whereas latent functions are unintended. This is further related to another of Merton's concepts- unanticipated consequences. Actions, according to him, have both intended and unintended consequences with everyone usually aware of the intended consequences, sociological analysis are thus required to uncover consequences

Relating this to the study, the structural functional perspective offers a useful insight into the intended and unintended consequences as well as the functional roles of microfinance institutions as poverty alleviation intervention which empowers women and consequently affects their level of income, education, expansion of business and provision of capital for new ones as its intended consequences or function. This enables women to become financially independent and reduces their level of poverty. Women are empowered and able to assist their spouse, family members and children and which may be viewed as an indirect function of microfinance hence the intervention is viewed as a strategy adopted to improve the general wellbeing of the clients and in turn their families.

\section{Methodology}

The study area was Edo state whose capital is Benin City. The 2006 population census indicated the State had a population of 3,218,332 including 1,460,461 male and 1,577,871 female with the latter having higher population. These figures reveal an increase of 48.2 per cent compared to the 1991 census. The state has 18 local government areas with its citizen mainly involved in agricultural activities and craftsmanship. The state was selected for the study due to the increased report of women trafficking in the region which was attributed to poverty and unemployment in the area (Onyeonoru, 2003; Jerome \& Owumi, 2007). The study is descriptive and cross-sectional in design. The purposive sampling technique was adopted in the collection of data at the community, institutional and individual level.

The study population consisted of women who had been clients of selected MFIs for over three years. The MFIs included three branches (Ugbowo, Iruekpen and Benin City) of Lift Above Poverty Organization (LAPO) with integrated health services (IHS) and four others without IHS in Edo state. Also included are selected microfinance officials such as Managers, Program officers and Client/ Credit Officers (COs) of the MFIs and the (women) representatives/executives (excos) of group/unions of the microfinance banks. Purposive sampling technique was adopted in the selection of samples at the state, local government, institutional and individual level. Three local government areas (LGAs) were selected out of the 18 LGAs in Edo State. The study area was also selected due to the presence of the headquarters of a renowned and internationally recognized MFI Lift Above Poverty Organization (LAPO) in the region, which established over 190 branches within and outside the state. The study adopted a triangulation of the quantitative and qualitative methods of data collection. This involved the use of survey method, In-depth Interviews (IDIs), Focus group discussions (FGDs) and key informant interviews (KIIs).

In summary therefore, a total of seven hundred and fifty copies of questionnaire were administered on 400 respondents in microfinance banks that integrate health-related services in their programmes and 350 respondents in microfinance banks that do not. Thirty-four (34) interviews consisting of fourteen (14) in-depth interviews and 20 key-informant interviews with prominent female clients and officials of microfinance institutions respectively were conducted, and finally eight (8) FGDs one for each microfinance and except LAPO Benin, where two FGDS were conducted. The FGDs and Interviews were monitored by a facilitator and an interviewer respectively. In both events, discussions were tape-recorded along side with note-taking. For the microfinance banks offering health-related services, the researcher paid visits to more of the unions that had benefitted from one health program or another.

The statistical package of the Social sciences (SPSS) was utilized using univariate and bi-variate unit of analysis. Statistical tools used included frequency distribution, Chi-square, cross tabulations and correlation. Demographic characteristics such as residential apartment, residential area, density of residential, age, educational attainment, income, household size, means of livelihood, occupation, work status, spouse occupation and spouse income were analyzed by cross-tabulating the variable with the categories of respondents. The qualitative data was transcribed and analyzed using the computer assisted data analysis (CAQDAS) package in line with the objectives of the study. 


\section{Results and Discussion}

The demographic characteristics of respondents for the study in table 1 below, revealed that nearly half of the respondents in the study fell within the ages of 31-40 years. This age range according to Aina, (1998), Otite and Ogionwo (2006) and Ehighiamusoe (2009) represents ages around which women are more active and productive in the informal sector, therefore contributing more to societal development. Again, slightly above half of respondents $(51.7 \%)$ had secondary education while very few $(8.7 \%)$ had tertiary education with a higher representation $(11.8 \%)$ of clients of the microfinance banks that offer health-related services. These findings support the opinion of Ehighiamusoe (2009) that many microfinance respondents in Nigeria lack tertiary education and formal skills.

The study however observed a significant difference in the educational qualification and income of clients from the two categories of microfinance banks. Respondents from microfinance banks with IHS were revealed through the study to have higher income and educational qualification, than clients from microfinance banks without IHS. This may not be disconnected from the fact that the microfinance that integrate health services educate and train their clients with emphasis on the need for formal education as expressed by the interviewed union leaders.

Over 80 percent of the women (from both categories of microfinance banks) are married. Women at some point had to be discreet about their status of being a widow, a separated or an unmarried in describing applicable marital status. Again, the high social value placed on the marital status of being "married" is unraveled as women depend on their husbands to guarantee that they will not default in repaying loans collected. Respondents who were singles and widowed were about $20 \%$ and covered by the strength of the majority who are married/ while almost half of the respondents $(46.5 \%)$, reside in face to face apartments. The level of dependency on the microfinance clients was observed to be high as majority revealed that they had at least two to three dependants both below and above 18 years of age either as their children or siblings staying with them. This supports the views of Daley-Harris 2002 that the influence of microfinance on the well being of clients extends even to their family members. The ages of dependants below and above 18 years were separated considering the fact that youth above this age in Nigeria are considered legally old enough to make decisions themselves and therefore could work and provide their means of livelihood.

Table 1: Demographic Characteristics of Microfinance Bank (MCB) respondents

\begin{tabular}{|c|c|c|c|c|}
\hline Characteristics & Total $\mathbf{N}=\mathbf{7 5 0}$ & $\begin{array}{l}\text { MBs with IHS } \\
\mathrm{N}=\mathbf{4 0 0}\end{array}$ & $\begin{array}{l}\text { MBs without IHS } \\
\mathbf{N}=\mathbf{3 5 0}\end{array}$ & Chi-square value \\
\hline \multicolumn{5}{|l|}{ Age of Respondents (\%) } \\
\hline $21-30$ & 12.0 & 12.5 & 11.4 & \multirow{4}{*}{$.043 * *$} \\
\hline $31-40$ & 47.1 & 43.5 & 51.1 & \\
\hline $41-50$ & 27.9 & 28.0 & 27.7 & \\
\hline Above 50 & 13.1 & 16.0 & 9.7 & \\
\hline \multicolumn{5}{|l|}{ Marital Status (\%) } \\
\hline Single/Never married & 6.1 & 6.1 & 6.1 & \multirow{4}{*}{.736} \\
\hline Married & 82.1 & 83.3 & 80.7 & \\
\hline Separated/Divorced & 1.7 & 1.5 & 2.0 & \\
\hline Widowed & 10.0 & 9.1 & 11.0 & \\
\hline \multicolumn{5}{|l|}{ Residential Type (\%) } \\
\hline Face to face apartment & 46.5 & 46.6 & 46.3 & \multirow{4}{*}{.236} \\
\hline One bedroom self-contained & 17.1 & 14.7 & 19.9 & \\
\hline $2-3$ bedroom flat & 32.7 & 34.9 & 30.2 & \\
\hline Bungalow/Duplex & 3.7 & 3.8 & 3.5 & \\
\hline \multicolumn{5}{|l|}{ Residential Area (\%) } \\
\hline Low density & 3.8 & 3.3 & 4.3 & \multirow{3}{*}{.754} \\
\hline Moderate density & 60.3 & 60.9 & 59.6 & \\
\hline High density & 36.0 & 35.9 & 36.1 & \\
\hline \multicolumn{5}{|c|}{ Dependants above 18 years $(\%)$} \\
\hline 1 & 17.4 & 19.5 & 15.6 & \multirow{5}{*}{.222} \\
\hline 2 & 38.3 & 42.2 & 33.9 & \\
\hline 3 & 18.7 & 18.7 & 18.7 & \\
\hline 4 & 12.4 & 10.4 & 14.7 & \\
\hline 5 and above & 13.1 & 13.1 & 13.1 & \\
\hline \multicolumn{5}{|c|}{ Dependants below 18 years $(\%)$} \\
\hline 1 & 18.7 & 17.5 & 20.1 & \multirow{5}{*}{.937} \\
\hline 2 & 24.0 & 24.6 & 23.4 & \\
\hline 3 & 30.5 & 30.4 & 30.5 & \\
\hline 4 & 19.5 & 19.8 & 19.1 & \\
\hline 5 and above & 7.4 & 7.7 & 7.0 & \\
\hline
\end{tabular}




\subsection{Socio-economic Characteristics of Respondents}

In table 2 , results showed that over half of the clients (51.7 percent) have secondary education, with a slightly higher proportion (52.1 percent) from microfinance banks with IHS as against 50.6 percent of clients who are from without IHS microfinance banks.

Table 2. Socio-economic characteristics of Microfinance Clients

\begin{tabular}{|c|c|c|c|c|}
\hline Characteristics & Total $\mathbf{N}=\mathbf{7 5 0}$ & $\begin{array}{l}\text { MBs with IHS } \\
\text { N=400 }\end{array}$ & $\begin{array}{l}\text { MBs without IHS } \\
\mathbf{N}=\mathbf{3 5 0}\end{array}$ & $\begin{array}{l}\text { Chi- } \\
\text { square }\end{array}$ \\
\hline \multicolumn{5}{|l|}{ Educational Qualification (\%) } \\
\hline No education & 5.9 & 2.8 & 9.4 & \\
\hline Non-formal education (vocational) & 6.9 & 5.8 & 8.3 & $.000 * *$ \\
\hline Primary & 26.8 & 27.1 & 26.6 & \\
\hline Secondary & 51.7 & 52.6 & 50.6 & \\
\hline Tertiary & 8.7 & 11.8 & 5.1 & \\
\hline \multicolumn{5}{|l|}{ Occupation $(\%)$} \\
\hline Farming & 2.0 & 2.0 & 2.0 & \\
\hline Trading & 86.8 & 87.7 & 85.8 & .893 \\
\hline Artisan & 9.9 & 9.0 & 11.0 & \\
\hline Private employee & 0.8 & 0.9 & 0.9 & \\
\hline Government employee & 0.4 & 0.5 & 0.3 & \\
\hline \multicolumn{5}{|l|}{ Monthly Income (\%) } \\
\hline N10000 and below & 18.7 & 4.5 & 9.1 & \\
\hline$¥ 10001-\approx 20000$ & 32.8 & 37.8 & 38.3 & \\
\hline$¥ 20001-\$ 30000$ & 22.1 & 28.5 & 17.1 & $.000 * *$ \\
\hline$\aleph 30001-丹 40000$ & 10.1 & 10.5 & 10.4 & \\
\hline$¥ 40001-丹 50000$ & 5.0 & 5.5 & 5.1 & \\
\hline Above $\$ 50000$ & 6.7 & 9.1 & 4.5 & \\
\hline \multicolumn{5}{|l|}{ Spouse Occupation (\%) } \\
\hline Farming & 4.4 & 3.8 & 4.8 & $026 * *$ \\
\hline Trading & 33.6 & 33.1 & 34.3 & \\
\hline Artisan & 40.7 & 45.4 & 34.6 & \\
\hline Private employee & 8.2 & 9.7 & 7.0 & \\
\hline Government employee & 10.8 & 10.8 & 10.8 & \\
\hline Spouse monthly Income $(\%)$ & & & & $003 * *$ \\
\hline 10000 and below & 4.6 & 4.5 & 4.7 & \\
\hline$\$ 10001-\$ 20000$ & 9.1 & 7.8 & 11.3 & \\
\hline 20001- $\$ 30000$ & 11.9 & 16.3 & 5.1 & \\
\hline$® 30001-丹 50000$ & 56.6 & 55.3 & 58.6 & \\
\hline Above $\$ 50000$ & 17.8 & 16.3 & 20.3 & \\
\hline
\end{tabular}

$* *=$ significant at 0.05

Also, a few of the respondents (5.9 percent) had no education while just a handful had learnt vocational skills (6.9 percent) ranging from hair dressing, to tailoring, to bead-making. However more clients from microfinance banks without IHS are represented within these descriptions than those from microfinance banks with IHS. The result confirms the views of Ehighiamusoe (2009) on the fact that most of the women in microfinance in Nigeria, particularly in Edo state, are not well educated, as majority are just secondary school certificate holders and may have some form of vocational skills.

Furthermore, majority of the respondents for both categories of microfinance banks, are into trading as an occupation. This represents not less than 86 percent for both groups. This distribution is not unconnected with fact that respondents for the study are supposed to be gainfully engaged in one micro enterprise to have access to microfinance loans so as to be able to pay back the loans they collect.

In addition, over 30 percent of clients' spouses from both microfinance banks are traders. The population of spouse of microfinance clients who are government employee for both categories are 10 percent, while 7 percent of them are private employee consisting of 8.2 percent and 9.7 percent for clients spouses from microfinance banks with and with IHS respectively. The chi-square value for the spouse occupation and spouse income, are both significant. Thus, revealing a significance difference between the occupation and income of the spouses 
from both categories of microfinance.

Findings revealed with reference to the income distribution of respondents that as the monthly earned income increased, more clients are represented in MBs with IHS than without IHS clients, while as the monthly earned income decreased, more clients are represented than HRS clients. Over 50 percent of the clients earned between $\$ 30,001-\$ 50,000$ and above per month. Again the proportion of clients who earn as much as an average of $\$ 30,000$ to $\$ 50,000$ points attention to the possibility that these women are not "very poor" except the microfinance loans had empowered them and improved their income to this level.

For spouses' income distribution, the trend is quite different as more spouses (20.3 percent) of microfinance banks with IHS earn above $\$ 50,000$ than those of clients from microfinance bank that offer health-related services (16.3 percent). Also, 58.6 percent of clients' spouse from microfinance banks without IHS as against 55.3 percent of clients' spouse from microfinance banks with IHS, earn between $\$ 30001-\$ 50000$. This probably explains why the residential type and area are not quite different for both clients as the spouse income distribution could have taken care of the residential apartments of the respondents. Aside from respondents' occupation, the chi-square values for the other entire variables are significant thus revealing a significant difference between these variable which determine the socio-economic characteristics of respondents.

Access to microfinance loans have been revealed to be major platform through which women are socioeconomically empowered as microfinance clients. Table 3 reveals the access to microfinance women in the study conducted that over $80 \%$ of the respondents had received between a $\$ 100,000$ to $\$ 500,000$ altogether which they paid back between 6 to 8 months with interest. The difficulty in accessing loans was reported by more $(24.7 \%)$ of clients from microfinance with health related services $(5.5 \%)$ than those from those from microfinance banks that did not integrated health related services.

It could also be observed from table 3 that more of the clients from microfinance banks with IHS (68.7 percent) as against 62.2 percent of clients from MBs without IHS had received loans between 3-5 times. While those who have received loans for over 5 times are more from the microfinance banks without IHS (24.0 percent) compared to 20.9 percent of clients from microfinance banks with IHS. The reason for the difference as is probably due to the fact that clients from MBs without IHS pay back their loans on or before 6 months thus given them a chance of having access to loans at least two times in a year if they so desire after payment. However, the interest rate for these MBs without IHS (35- 40\% per annum) are higher and the amount to be paid back per week or month as the case may be is usually higher compared to those of the microfinance banks with IHS whose interest rates are lesser (30 percent) and give a longer space of time for loans to be paid back (usually 8 months).

Table 3. Respondent's accessibility to microfinance loans

\begin{tabular}{|c|c|c|c|c|}
\hline Variables/Categories & $\begin{array}{l}\text { Total } \\
\mathrm{N}=750\end{array}$ & $\begin{array}{lll}\begin{array}{l}\text { MBs } \\
\mathrm{N}=400\end{array} & \text { with IHS } \\
\end{array}$ & $\begin{array}{ll}\text { MBs } & \text { withou } \\
\mathbf{N}=350 & \\
\end{array}$ & IHS \\
\hline \multicolumn{5}{|l|}{ Years of being a client (\%) } \\
\hline 3 to 5 years & 42.0 & 39.3 & 45.1 & \\
\hline Above 5 years & 58.0 & 60.8 & 54.9 & \\
\hline \multicolumn{5}{|l|}{ How loan is received $(\%)$} \\
\hline Through the bank & 98.2 & 97.5 & 99.1 & \\
\hline Through group lending & 1.8 & 2.5 & 0.9 & \\
\hline \multicolumn{5}{|c|}{ No. of times received loan (\%) } \\
\hline $1-2$ & 10.4 & 13.8 & 6.6 & \\
\hline $3-5$ & 68.7 & 62.2 & 76.0 & \\
\hline Above 5 & 20.9 & 24.0 & 17.4 & \\
\hline \multicolumn{5}{|c|}{ Total amount of loan received (\%) } \\
\hline Below N50,000 & 6.4 & 9.3 & 3.1 & \\
\hline N50,000-N100,000 & 6.8 & 8.8 & 4.6 & \\
\hline $\mathrm{N} 100,001-\mathrm{N} 200,000$ & 39.2 & 34.3 & 44.9 & \\
\hline $\mathrm{N} 200,001-\mathrm{N} 500,000$ & 44.1 & 43.5 & 44.9 & \\
\hline Above N500,000 & 3.5 & 4.3 & 2.6 & \\
\hline \multicolumn{5}{|l|}{ Repayment of first loan (\%) } \\
\hline Below 6 months & 0.7 & 1.3 & 0 & \\
\hline 6 months & 46.7 & 0 & 100 & \\
\hline Above 6 months ( 8 months) & 52.9 & 98.8 & 0 & \\
\hline \multicolumn{5}{|l|}{ Loan difficult to get (\%) } \\
\hline Yes & 24.7 & 5.5 & 46.6 & \\
\hline No & 75.3 & 94.5 & 53.4 & \\
\hline
\end{tabular}

$* *=$ significant at 0.05

Also, depending on the kind of business and amount invested, it is may be easier for those who pay less 
amount of money with less interest to save more money than those who pay back more money with more interest in shorter periods even those they can collect more. Since the access to loan also depends on the savings, those who have lesser savings are less likely to have access to other loans, even after they had paid the previous.

With reference to the amount of loans received altogether, the study revealed that a significant proportion of the clients from both microfinance banks (44.9 percent for both categories) had access to amount above N100, 000 to N200, 000, and amount above N200, 000 to N500, 000. However, more from HRS microfinance banks had access to the amounts. More clients from these microfinance banks though less than 5 percent, had access to above N500, 000. These categories of clients are either very old members who had accessed loans several times or members in large businesses that are able to pay back loans quickly, save enough, and collect more loans.

In terms of repayment schedule as earlier discussed, clients from health-related service providing microfinance banks pay back collected loans within a space of 8 months except in cases where asset loans which are usually bigger are collected. However, clients from microfinance banks who do not provide health-related services are expected to pay back the loans they collect within a space of 6 months except in cases where larger or special loans are collected. The responses of clients in this regards confirms these, as all the clients of microfinance banks without IHS (100 percent) stated that they pay back their loans within 6 months while, 98.8 percent of clients from microfinance banks with IHS stated that they pay back loans within a space of 8 months, which also reveal that they collect simple micro enterprise loans to expand their businesses.

Women's accessibility to loan is also influenced a great deal by the difficulty or ease experienced in accessing the previous loans. Thus, when respondents were asked whether they experienced difficulty in accessing the loans, majority of the respondents (75.3 percent) reported that the loans were not difficult to get. However, there was a great disparity in the responses given by the clients in this regards as clients from microfinance banks without IHS (46.6 percent) experienced more difficulty in accessing loans, than those from microfinance banks with IHS (5.5 percent). Above, 94.5 percent of clients from microfinance banks with IHS as against, 53.4 clients from microfinance banks without IHS reported that they did not experience difficulty in accessing loans. Respondents who experience difficulty in accessing the loans reported that they were either not aware of the criteria before applying for the loans, or had tough time meeting the criteria for accessing the loans. A representative of the women from a non-health related microfinance states:

the loans are usually not difficult to access if clients meet the conditions.

If they make their deposits/savings consistently and have quality guarantor that will sign surety for them. Most clients who cannot have access to loans do not meet the conditions. Despite being informed at the point of meeting and introducing potentials clients, some may still say that they did not know that they were supposed to meet these conditions before getting loans can you imagine? Although, one who are yet to complete payment for previous loan will not have access except she has cleared it and saved too. (union leader/36/IDI/Ekpoma/semi-urban)

A client officer from a health-service related microfinance bank reported in line with the above by stating:

Women are very good at owing and not paying back and we do not take such fact for granted and that is why we have to ensure that they make their weekly contributions correctly and get a reasonable savings compared to the loans they are going to get say one-third savings. A potential loan applicant is also expected to have a guarantor that can pay back in case she defaults and her group or union must trust and testify that she will not disappoint them. Otherwise it will affect their access to loans the next time. (Client officer/34/KII/Benin town/urban)

Responses of the bank managers who were interviewed were also very similar. The opinions of discussants from microfinance banks without IHS in the Focus Group discussions were quite interesting as five discussants were of the opinion that loans were not easily accessible while the other five stated that they are easily accessible provided the conditions are met. A striking view from a discussant that supports the former opinion states thus:

How can I say the loans are not difficult to access when I cannot get loan for some business idea at anytime I desire simply because I have not cleared the first loan, I missed some cheap goods which would have helped my business a great deal three months ago because I could not have access to common N80,000. Why? They said I must clear the one I owe. How is that possible? Besides, am not running away now. If the microfinance is truly out to alleviate poverty and empower us, I should not have been deprived of that opportunity that is why I say the loans are not easily accessible. (married /38/FGD/Auchi/urban)

Another discussant with a contrary opinion from the FGD however states: 
If everybody is given loans anyhow without conditions to meet, the microfinance banks would have packed up $^{1}$ and we will not even be here to get anything. I strongly believe that the conditions are okay and are there to curtail our shortcomings. If you meet the conditions, you will surely get the loan hence they are accessible after all we do not have any collateral to collect money from commercial banks that is why we don't go there. (married/36/FGD/Auchi/urban)

The general consensus is that clients of microfinance banks are expected to meet conditions with regards to clearing outstanding loans, having saved specific amount with microfinance bank, having a credible guarantor and group/union supports before they can have access to loans. Thus, loanees who meet these conditions do easily access subsequent loans which falls within the limit of their savings, while those who do not, will not be granted subsequent loans. Clients are therefore expected to have adequate knowledge of these conditions and ensure that they are met before applying for loans.

\subsection{Influence of Microfinance on the Socio-economic status of women}

In other to determine the influence of microfinance on the socio-economic status of clients, a regression analysis was done to show the influence of access to loan on respondents' income, occupation and education. Access to loan had influence on the income of respondents $(\mathrm{r}=.023)$, education and occupation $(\mathrm{r}=.05)$. From the foregoing therefore, microfinance has influenced on the socio-economic status of their clients and this corroborates the findings of previous studies (Irobi 2007; Dunford, 2002; Watson 2005;)

From the qualitative responses however, a handful of respondents from MBs without IHS revealed that microfinance had an influence on their occupation and accommodation/residential type. A striking response from an interviewed union representative stated in an MB without IHS revealed a positive influence of microfinance on the occupation and residential project. The widow says:

well the loan I have received has helped me in my business in the sense that it has expanded the business. But I had also taking some money from the business to start developing my land which I inherited from my late husband and building my own house. Although I am practically struggling but the truth is, it was after four years that I joined microfinance that I was able to take money confidently from the business to be building my house gradually otherwise my business would have collapsed. (Union leader/36/IDI/Benin town/urban)

Another response form an interviewed union representative from a non-health providing microfinance bank also reveals an influence on the occupation she says:

I am not planning to go back to school. So, I don't know the connection between microfinance and my education except you are talking about my children and relatives whom I am training in school because it is from the same business I take money for their schooling. But if you are talking about my business, then we can say that the loan I have received has helped me to expand it a little. Although I am still seriously managing and need more money and bigger loans but I cannot get it now because I have not finished paying the last one I collected. (union leader/34/IDI/Jattu/semi-urban)

The above response reveals that although microfinance expands the existing business of clients and empowers, them financially, it has not adequately reduced or alleviated them from poverty partly due to the fact that the finances are not enough as they also spend from it to cater for their poor dependants. Quite related to the above response is that from another respondent from a microfinance bank with integrated health-related services who also related the influence of microfinance on her income, occupation and family in general. She says:

Before I joined a microfinance bank, I was borrowing money when am desperate to pay my children's school fees or buy food stuff at home and usually end up getting embarrassed for not paying back the money on time because of other needs that arise. However, when I receive loans from microfinance, the modalities for paying back does not give room for me to be embarrassed, hence my business gradually expands and I can save some money for my family's need. Although I get very broke at time when I do not make enough sales especially because I must remove

\footnotetext{
${ }^{1}$ Packed up in the context of the response means gone bankrupt
} 


\section{the money for paying back my microfinance loans. (Union leader/37/IDI/Auchi/Urban)}

Clients from microfinance banks with integrated health-related services were however emphatic about the influence of microfinance on their businesses, occupation and education. Majority of the discussants in the FGD stated that the microfinance had expanded their businesses. Some added that they were able to acquire properties and assets with the loans which had aided their business. Those in provision and mineral businesses for instance said they had acquired fridges and generators which cools their drinks and retains their customers so that they can boast of increased turn-over. Also, most interviewees and discussants when discussing the issues of microfinance influence in education added that they had been able through microfinance to train their children and siblings in schools. Thus, the influence might not be directly on their personal educational attainment for clients, but on contributing to the education of their children and other dependants. Some stated that they trained as many as three to four of their relatives in schools through microfinance funds which expanded their business enough to retrieve reasonable cash that will not crumble the business for relatives education. A discussant in the FGDs with the health-related service providing microfinance bank in her response supported the views of (Saha 2011) on how microfinance influences the social networking of women thus improving their relationship, selfconfidence and self-image. The woman says;

One major way I will say that microfinance has improved my social and economic status is in the fact that my access to microfinance loans has improved my business and finances and this has helped me to be very useful and influential in my meetings and associations. People now regard me as somebody and respect me. Apart from that, I have made good friends in my microfinance union whom I can regard as family and call on any time for assistance hence I am now very confident about myself and more social in relating with people. (union leader/31/FGD/Benin town/urban)

From the above responses, it could be deduced, that microfinance does not only empower women financially, but it influence extends beyond financial/economic empowerment to empowering them socially and psychologically. Microfinance influence several facets of their clients lives and these include their occupation, education and other aspects of their lives and those of their family members. This is so as responses confirm that clients from microfinance have contributed most especially in training their children, siblings and some of the relatives in schools or other vocational skills. Thus, the manifest function of microfinance as explained by the theory of functionalism, is reflected in the empowerment if women and alleviating them from poverty, while the latent function extends to the family members of microfinance clients.

\section{Conclusion}

In line with other studies abroad, microfinance has been revealed to have a positive influence on the socioeconomic status of women. This is obvious in the fact that through microfinance, women have been able to access loans that have been helpful in the expansion of their business and empowered them financially to cater for themselves and their family members. The influence of microfinance on the health of clients is more observed among clients from microfinance that integrate health related services. However it is expedient to note the very poor in the society are yet to be reached and alleviated from poverty, since union leaders who are expected to admit them avoid and refuse to do so for fear of being disqualified from accessing loans if such very poor who may be faced with several poverty challenges and default in paying back the loans they collects. As such, the primarily aim of establishing microfinance institutions to reach out to the "very poor" still remains unfulfilled.

\section{Recommendations:}

In line with the findings, the study therefore recommends that increased support for both locally and internationally recognized microfinance banks by the government and other international organization should be provided for microfinance institutions in Nigeria. This will influence a reduction in the interest rates and repayment time of clients and enable microfinance banks make opportunity available for the very poor to access microfinance loans. It will also help existing clients to plan better with their income and experience alleviation and reduction in their state of poverty.

Consideration should be given to the very poor who are unable to provide guarantor to stand in for them to have access to loan with maximum support on how to make their business productive through adequate trainings and follow-up so as to make them alleviated from poverty and repay loans collected. This will empower the very poor and make the primary goal of establishing microfinance bank which has to do with reaching out to the poor to become a reality in Edo state. 


\section{REFERENCES}

Aina, A. 1998. "Women, Culture and Society" (pp 3- 33) (eds) by Sessay, A and Odebiyi,. O. In Nigeria Women in Society and Development. Ibadan. Dokun Publishing House

Cheston, S and Kuhn, L. 2002. "Empowering Women Through Microfinance". New York. UNIFEM.

Daley-Harris, S. 2005. "State of the Micro credit Summit Campaign 2005". Micro credit Summit Campaign.

Daley-Harris, S eds.2002. "Pathways Out of Poverty: Innovations in Microfinance for the Poorest Families". Bloomfield, Connecticut, Kumarian Press, Inc.

Dunford, C. 2002 . "Building Better Lives: Sustainable integration of Microfinance with Education in Child Survival, Reproductive Health and HIV/AIDS Prevention for the Poor Entreprenuers." In Sam-Dalley Harris (ed.) Pathways Out of Poverty: Innovations in Microfinance for the Poorest Families". Bloomfield, Connecticut, Kumarian Press, Inc.

FMOH. 2004. Health sector reform programme: strategic thrust with a logical framework and plans of action, 2004-2007.

FMOH. 2004. Revised national health policy.

Irobi, N. 2007. "Microfinance and Poverty Alleviation. A case of Obazu Progressive Women Association Mbieri, Imo State Nigeria" An unpublished on-line Thesis in Economics (Business Administration). SLU, Department of Economics, Uppsala.

Jerome P. A. and Owumi B.E 2007 “ Women Trafficking and the risk of contracting HIV/AIDS among the trafficked in Edo State In African Journal for Psychological Study of Social Issues, Vol. 12, No.1 and 2. Pgs 68-83,

Johnson, D. 2000. Nigeria; Country Health. Briefing paper produced by DFID's health System Resource Centre for the United Kingdom Department for International Development.

Littlefield, E. et al 2003. "Is Microfinance an Effective Strategy to Reach the Millennium Development Goals?" Washington, D.C, Consultative Group to Assist

MkNelly, B. and Dunford, C. 1998. "Impact of Credit with Education on Mothers and Their Young Children's Nutrition: Lower Pra Rural Bank Credit with Education Program in Ghana.” Davis, California: Freedom From Hunger

MkNelly, B. and Dunford, C. 1999: “Impact of Credit with Education on Mothers and their Young Children's Nutrition: Credit with Education Program (CRECER) in Bolivia” . Davis, California. Freedom From Hunger.

Millar, J and Gledinning, C. 1989. " Gender and Poverty, Journal of Social Policy. Vol 18. No. 3.

Morduch, J. 2005. " Implementing the Microenterprise Results and Accountability Act of 2004." Washington, D.C. Testimony for the House International Subcommittee on Africa, Global Human Rights and International Operations.

National Bureau of Statistics (NBS) 2004. Nigeria Living Standard Survey. Federal Republic of Nigeria.

Ofori-Adjei, A. 2007. Microfinance; An alternative means of Healthcare Financing for the poor In Global Theme Issue on poverty Ghana Medical Journal Vol 41. No. 4, pages 193-194.

Okojie C.G 1960 "Islam Native Laws and Customs. Lagos National Press.

Onyeonoru, I. 2003 Push Factos in Girls'Trafficking for International Commercial Sex Work and Gender Implications: A Study of Benin, Edo State African Journal of Peace and Conflict Studies Vol. 1, pp.118-139.

Oladumi, E. 1999. “The Dimensions of Poverty in Nigeria: Spatial Sectoral, Gender et al in Bullion, a quarterly publication of the Central Bank of Nigeria. Vol 23. No. 4 October/December 1999.

Olutayo. A. 2005. Sociological Correlates of Reproductive Health among the Street Children Ibadan.

Ozo-Eson A. 2008. "Microfinance and the Empowerment of Women"

Otite, O and Ogionwo, W. 2006. Introduction to Sociological Studies. Heinemann Educational Books Nigeria plc Ibadan

Sinclair, S. 2003. " Poverty and Social Exclusion in Haralambos et al (2004) Sociology: Themes and Perspectives. Hapercollins publishers Limited Hammersmith W68JB

Sofo, C. and Toni, P. 2008. "Women and Poverty in Nigeria" In Measuring Poverty in Nigeria. Oxfam in Oxford.

Soyibo, A. 2005. National health accounts of Nigeria, 1998-2002: final report submitted to the World Health Organisation

Strenski, T. and Baum B. H. 1989. Short communication, Thailand: current public health perspectives. International Journal of Health Planning and Management. 4: 117-124

Todd, H. 1996. Women at the Center. Dhaka, Bangladesh : University Press Limited.

Taiwo, P. A. and Owumi, B. E. 2014 "Integrating Health Services into Microfinance Operations for Sustainable Poverty Alleviation: The Case of Female Clients in Edo State" In Ibadan Journal of the Social Sciences Vol. 12. No.2 Pg 125-146

Taiwo, P. A, Owumi, B. E. And Oyekanmi O. 2017 “Group Methodology and Womens' Access to Soft 
loans in Selected Microfinance Institutions in Edo State Nigeria" African Journal for the Psychological Study of Social Issues Vol. 20. No.2 pg 201-

UNFPA 2005: Beijing at Ten: UNFPA's Commitment to the Platform for Action 2005. New York, United Nations Population Fund (UNFPA). 